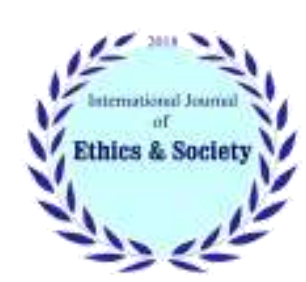

International Journal of Ethics \& Society (IJES)

Journal homepage: $\underline{\text { www.ijethics.com }}$

Vol. 3, No. 1 (2021)

(Original article)

\title{
Designing a Good Corporate Governance Model in the Context of Ethics and Rationality
}

\section{Ghazaleh Nazari-Aref ${ }^{a}$, Behzad Farrokh-Seresht ${ }^{\text {a* }}$, Ghorbanali Agha-Ahmadi ${ }^{\text {, }}$ Saeed Eslami ${ }^{b}$}

a) Dept. of Public Management, Chalous Branch, Islamic Azad University, Chalous, Iran.

b) Dept. of Political Sciences, Chalous Branch, Islamic Azad University, Chalous, Iran.

\section{Abstract}

Background: Corporate governance is one of the most important business issues that depends on business ethics and rationality. Therefore, in this research, the model of corporate governance in the context of ethics and rationality was designed.

Method: The present study was qualitative and based on the grounded theory. The study population consisted of faculty members and Ph.D. students, experts and specialists, and managers and staff of Tehran Water and Sewerage Company who have a good view in the field of corporate governance. 24 people from the population by sampling method Snowballs were selected as the sample until they reached theoretical saturation. The analysis tool was a semi-structured interview and finally the data were analyzed by triple coding method (open, axial and selective) in MAXQDA software.

Results: A total of 1032 significant phrases were identified in the interviews, from which 99 codes were extracted and classified into 29 main concepts, and with the axial coding method, they were placed in a suitable position and formed the research model.

Conclusion: If this model of corporate governance is applied in the context of ethics and rationality, it can create consequences such as improving the operational performance of the organization, improving business ethics, trust and value creation for shareholders, etc. for the organization and stakeholders.

Keywords: Corporate governance, Business ethics, Rationality

\section{Introduction}

Governance is a process that can reduce the power of managers to pursue personal interests and improve the performance of companies by increasing the lack of focus on controlling companies (1) and thus achieve the promotion and effectiveness of

*Corresponding Author: Email: farrokhsereshtbehzad0@gmail.com

Received: 1 Feb 2021

Accepted: 5 Mar 2021 
companies. The most important corporate governance mechanism, i.e. the board of directors, always seeks to manage the interests of the organization (2) to encourage senior management to take steps to increase the interests of shareholders (3), manage their interests and ensure the realization of human rights. It performs these activities correctly and without error and with the focus on the law (4). Good corporate governance follows the same concepts at the organizational and corporate levels. Good governance is a process that can protect the interests of all stakeholders in a company and control the various groups of the organization, i.e. managers, employees and shareholders using legal mechanisms, while also leading to the growth of an ethical culture in participate corporate governance as a philosophy and attitude is significantly dependent on social responsibility and business ethics (5). By increasing the power of consumer movements and raising awareness among stakeholders, companies have found that stakeholders and other consumers engage in immoral activities such as financial irregularities, tax evasion, poor quality products and services, bribes for employment, non-compliance with environmental laws and conditions. Risky work, they are not careless. They focus on corporate governance as a control mechanism that ensures the optimal use of human, physical and financial resources. The framework of corporate governance depends on the ethical, traditional, orderly and legal environment of the community (6).

Today, protecting the public interest, respecting the rights of shareholders, promoting information transparency and requiring companies to fulfill social responsibilities are among the most important ethical ideals that have been considered more than ever by various regulatory and executive authorities. Achieving these ideals requires the existence of sound rules and appropriate enforcement mechanisms, the most important of which is the corporate governance system or corporate governance (7). Thus, corporate governance can be visualized as a beacon that illuminates part of the scene in which corporate governance processes take place. Each light illuminates only one part of the scene from one angle (8).

42

Available at: www.ijethics.com
In order to have good corporate governance, along with business ethics, one must also pay attention to rationality. The progress of human society must be measured, both in terms of instrumental work or action, and in terms of interaction or communication action. These two spheres, while communicating with each other, each have their own rationality. In capitalist society, relational rationality is contrasted with instrumental rationality. This contradiction manifests itself in the form of a crisis of legitimacy. To address this shortcoming, some scholars articulate a comprehensive meaning of rationality that includes both tools and goals. He calls this rationality "holistic rationality." In this rationality, appropriate goals and appropriate tools are pursued to achieve those goals (9).

Given what has been said, the concept of corporate governance is a progressive and new concept in the growth and development of enterprises, especially large enterprises. In corporate governance, in addition to theoretical discussions, there is a lot of emphasis on the formulation and maintenance of excellent ethical and professional values in the workplace. These value strategies are prescribed with the aim of institutionalizing the process of controlling and safeguarding the interests of all stakeholders, in the words and actions of all stakeholders of the organization - from board members and the board of directors to individual employees. It is obvious that the adoption of practical methods in this field should be done within the framework of the value system of societies; It also seems that achieving the lofty goals of corporate governance and its implementation and protection, along with paying attention to ethics, requires rationality, and in different situations to achieve a specific goal, various types of rationality should be used properly. Given the lack of proper explanation of this issue in previous research and the existing theoretical gap, this study intends to provide a model of good corporate governance in the context of ethics and rationality and explain the role of each type of rationality in achieving the transcendent goals of corporate governance. 


\section{Material \& Methods}

This is an applied research, in terms of the type of data, it is a qualitative study. The statistical population of the present study was professors and $\mathrm{PhD}$ students and specialists of Tehran Water and Sewerage Company who had sufficient information and a good view of corporate governance. Until the theoretical saturation was reached, 24 people were selected by snowball sampling. It includes 9 professors, 4 Ph.D. students and 12 experts and specialists of Tehran Water and Sewerage Company. Also, 17 respondents were male and 7 were female. The tools used in this study were semi-structured interviews and finally the data were analyzed by MAXQDA software using three coding methods (open, axial and selective).

\section{Results}

\section{Open coding}

At this stage, the data obtained from the interviews were reviewed and research-related concepts were extracted. A total of 1,032 significant terms were identified in the interviews, which were identified and divided into 99 unique initial codes.

\section{Axial coding}

The researcher's task at this stage was to "categorize and compare" the titles extracted from the data. Axial coding leads to the creation of groups and categories. All similar codes are in their own group. The output of this step also categorized 99 extracted codes into 29 main concepts. These concepts constitute the main categories of research. The main categories identified in this study are listed in table 1 along with a brief description of each.

Table 1: Main categories of research

\begin{tabular}{|c|c|}
\hline Concept & Descriptions \\
\hline Corporate governance & $\begin{array}{l}\text { A respondent on good corporate governance at ABFA Tehran states: Service } \\
\text { companies such as ABFA Tehran have an independent legal personality whose } \\
\text { management should be such that in addition to protecting the interests of share- } \\
\text { holders, the interests of other stakeholders, including employees, customers, } \\
\text { government and Also provide for the community; And it needs a control system } \\
\text { to monitor, report and comply with the company's framework and regulations } \\
\text { in the event of a conflict of interest. "These require the implementation of a } \\
\text { good corporate governance model in Tehran Province Water and Sewerage." }\end{array}$ \\
\hline Rationality & $\begin{array}{l}\text { Rationality refers to the use of reason to acquire knowledge. There are different } \\
\text { divisions for rationality, each of which depends on the individual's will and ac- } \\
\text { tion to make a decision. Instrumental rationality refers to the best way to achieve } \\
\text { a goal under any circumstances. Critical rationality refers to thinking and rea- } \\
\text { soning in the usual ways and customs and reaching for new ways. Communica- } \\
\text { tion rationality refers to rationality in dealings, relationships, and coordination, } \\
\text { and legal rationality to rationality in adhering to rules and standards. In this } \\
\text { study, six types of rationality that can be effective in applying strategies were } \\
\text { identified, which are instrumental rationality, value rationality, communicative } \\
\text { rationality, critical rationality, legal rationality and strategic rationality. }\end{array}$ \\
\hline Ethics & $\begin{array}{l}\text { Undoubtedly, morality and rationality are intertwined, and moral rationality re- } \\
\text { fers to the consideration of values and ethics in choosing the best way. }\end{array}$ \\
\hline $\begin{array}{l}\text { Type of joint stock company (ownership and } \\
\text { control) }\end{array}$ & $\begin{array}{l}\text { Managers try to maximize their own interests, which are not necessarily in line } \\
\text { with the interests of the owners. The type of joint stock company that includes } \\
\text { the identity of the institutional shareholders, the concentration of ownership, } \\
\text { the degree of control and supervision; It is one of the conditions that requires } \\
\text { corporate governance. }\end{array}$ \\
\hline $\begin{array}{l}\text { Type of structure and responsibilities of the } \\
\text { board }\end{array}$ & $\begin{array}{l}\text { The size of the board of directors, the independence of the board of directors, } \\
\text { the composition of the board of directors, the ratio of non-executive members } \\
\text { in the composition of the board of directors in this research indicate the type } \\
\text { of structure and responsibilities of the board of directors that can require good } \\
\text { corporate governance. }\end{array}$ \\
\hline $\begin{array}{l}\text { The need for transparency and disclosure of } \\
\text { information }\end{array}$ & $\begin{array}{l}\text { The need for transparency and disclosure of information: The quality of disclo- } \\
\text { sure is the amount of information provided by companies in the context of } \\
\text { basic financial statements or in accompanying notes to assist in decision making. } \\
\text { In this research, four codes of financial reporting, information transparency, } \\
\text { quality disclosure of information, appropriate accountability and timely are }\end{array}$ \\
\hline
\end{tabular}


Farrokh- Seresht B. et al.

International Journal of Ethics \& Society (IJES), (2021) Vol. 3, No. 1

\begin{tabular}{|c|c|}
\hline & $\begin{array}{l}\text { known as the necessary dimensions of transparency and disclosure of infor- } \\
\text { mation. }\end{array}$ \\
\hline $\begin{array}{l}\text { Establishing justice and fairness among } \\
\text { stakeholders }\end{array}$ & $\begin{array}{l}\text { If the various types of injustice are understood, the needs of the individual may } \\
\text { be harmed and dissatisfied. Be, take action. In this study, four codes of justice } \\
\text { in dealing with violations, fair and proportionate laws in dealing with all stake- } \\
\text { holders, ensuring the interests of stakeholders with equal priority, and efforts } \\
\text { to reduce discrimination between stakeholders are recognized as dimensions of } \\
\text { justice and fairness. }\end{array}$ \\
\hline $\begin{array}{l}\text { The need to pay attention to the role of stake- } \\
\text { holders and respect their rights }\end{array}$ & $\begin{array}{l}\text { Corporate governance is designed with the ultimate goal of achieving account- } \\
\text { ability, transparency, justice and respect for the rights of stakeholders in com- } \\
\text { mercial companies. In this research, this concept is recognized by three codes: } \\
\text { the need to protect the rights of all stakeholders in the company's laws, the need } \\
\text { to increase the satisfaction and commitment of stakeholders to the company. }\end{array}$ \\
\hline $\begin{array}{l}\text { The need to reduce corruption and financial } \\
\text { abuses }\end{array}$ & $\begin{array}{l}\text { Good corporate governance prevents or at least minimizes its negative conse- } \\
\text { quences. In this study, the codes to prevent the occurrence and spread of cor- } \\
\text { ruption, efforts to reduce violations, the need to prevent any financial abuse, } \\
\text { the need to prevent the preference of relationships over the criteria are indica- } \\
\text { tive of this variable. }\end{array}$ \\
\hline Tendency to privatize companies & $\begin{array}{l}\text { Privatization is an administrative, financial, and legal process implemented by } \\
\text { governments in many countries around the world to reform the country's econ- } \\
\text { omy and administrative system. In this study, the concept of the tendency to } \\
\text { privatize companies is explained by four codes: the need to reduce the scope of } \\
\text { public sector activity, increase competition, and expand the capital market and } \\
\text { the culture of participation at the national level, the need to reduce government } \\
\text { deficits and debts. }\end{array}$ \\
\hline Economic conditions governing society & $\begin{array}{l}\text { A country's macroeconomic policies affect the financial performance of com- } \\
\text { panies and their growth and development. Choosing the source of a company's } \\
\text { financing is crucial to corporate governance and its future successful develop- } \\
\text { ment. Inflation and recession are among the harmful economic phenomena that } \\
\text { most countries have struggled with at some point in their economic history. In } \\
\text { this study, three codes of inflation and economic recession, employment status, } \\
\text { economic status of society have been explained under the title of economic } \\
\text { conditions of society. }\end{array}$ \\
\hline $\begin{array}{l}\text { Policies and laws of government and govern- } \\
\text { ing institutions }\end{array}$ & $\begin{array}{l}\text { By prioritizing, legislatures must legislate to create an efficient market-based } \\
\text { economy and shrink government. Formulating and proposing new laws in order } \\
\text { to implement good corporate governance is one of the duties of the govern- } \\
\text { ment and governing institutions. In this research, this concept has been ex- } \\
\text { plained with four codes of correct implementation of existing laws, policy dom- } \\
\text { inance over the administrative system, the nature of governance laws and regu- } \\
\text { lations, and the coordinating role of governance in implementation. }\end{array}$ \\
\hline Corporate social responsibility & $\begin{array}{l}\text { Organizational social responsibility includes the economics, law, ethics and hu- } \\
\text { manitarian expectations of business units that extend to all stakeholders. Four } \\
\text { codes for improving social welfare, environmental issues, social challenges such } \\
\text { as employment. Women's issues, etc., socially accepted values in this study ex- } \\
\text { plain the concept of corporate social responsibility. }\end{array}$ \\
\hline Develop and adopt appropriate strategies & $\begin{array}{l}\text { Strategy means setting long-term goals in the organization and preparing appro- } \\
\text { priate action plans and allocating the resources needed to achieve these goals. } \\
\text { Extensive, all-encompassing and critical changes and transformations resulting } \\
\text { from these changes in the current situation of the country have faced organiza- } \\
\text { tions with many challenges. In this research, this concept has been explained } \\
\text { with four principles of principled planning code and adopting an appropriate } \\
\text { strategy, formulating a vision, values and mission in accordance with corporate } \\
\text { governance, a common effort to achieve the company's goals. }\end{array}$ \\
\hline $\begin{array}{l}\text { Appropriate rules and regulations and moni- } \\
\text { toring its proper implementation }\end{array}$ & $\begin{array}{l}\text { Undoubtedly, one of the most obvious things in achieving the goals is to ob- } \\
\text { serve the standards and laws governing the organization. Controlling and su- } \\
\text { pervising the proper implementation of laws and regulations, observing legal } \\
\text { requirements, enacting structured laws and regulations are the three codes that } \\
\text { explain the concept of appropriate laws and regulations and monitoring its } \\
\text { proper implementation in this research. }\end{array}$ \\
\hline $\begin{array}{l}\text { Organizational culture is in line with the val- } \\
\text { ues of corporate governance }\end{array}$ & $\begin{array}{l}\text { Organizational culture is a set of common values, beliefs, beliefs, assumptions } \\
\text { and norms that govern the organization. The four codes of general consensus } \\
\text { in the implementation of corporate governance, observance of ethical principles }\end{array}$ \\
\hline
\end{tabular}


Farrokh- Seresht B. et al.

International Journal of Ethics \& Society (IJES), (2021) Vol. 3, No. 1

\begin{tabular}{|c|c|}
\hline & $\begin{array}{l}\text { and organizational behavior, the existence of a culture of consultation and par- } \\
\text { ticipation in affairs, the existence and strengthening of appropriate organiza- } \\
\text { tional culture indicate the organizational culture in this study. }\end{array}$ \\
\hline $\begin{array}{l}\text { Experienced, capable, ethical, and commit- } \\
\text { ted board of directors }\end{array}$ & $\begin{array}{l}\text { The board of directors is responsible for policy-making, supervision and man- } \\
\text { agement of the company. The board of directors is the focal point of the com- } \\
\text { pany's success and in this respect must have the highest standards of integrity, } \\
\text { management, ethics and knowledge. Responsible and committed board of di- } \\
\text { rectors, knowledgeable and expert board of directors, experienced and capable } \\
\text { board of directors, and the board of directors has a four-code governance con- } \\
\text { sciousness that explains the above concept. }\end{array}$ \\
\hline $\begin{array}{l}\text { Establish a balance between corporate gov- } \\
\text { ernance and organizational characteristics }\end{array}$ & $\begin{array}{l}\text { In this study, accurate explanation of powers and responsibilities, organizational } \\
\text { structure that facilitates corporate governance, facilitating proper supervision } \\
\text { and control and feedback, coordination and healthy and constructive commu- } \\
\text { nication are considered as organizational characteristics appropriate to corpo- } \\
\text { rate governance. }\end{array}$ \\
\hline $\begin{array}{l}\text { Training and knowledge sharing between } \\
\text { members }\end{array}$ & $\begin{array}{l}\text { Teaching the specific principles and goals of corporate governance, sharing ex- } \\
\text { periences and knowledge among members, using and modeling successful cor- } \\
\text { porate governance systems, strengthening the spirit of learning and teaching } \\
\text { among members, are four codes that explain the concept of education and } \\
\text { knowledge sharing. }\end{array}$ \\
\hline $\begin{array}{l}\text { Establish appropriate relationships with } \\
\text { stakeholders and stakeholder participation }\end{array}$ & $\begin{array}{l}\text { The main foundation of corporate governance is based on good relationships. } \\
\text { In this research, four codes for removing communication barriers and ambigu- } \\
\text { ities for all stakeholders, trying to create positive relationships and a sense of } \\
\text { empathy between stakeholders, holding joint meetings and involving stakehold- } \\
\text { ers in decision-making, providing periodic reports of actions to stakeholders; } \\
\text { Explain the concept of establishing appropriate relationships with stakeholders } \\
\text { and stakeholder participation. }\end{array}$ \\
\hline Appropriate performance evaluation system & $\begin{array}{l}\text { A targeted evaluation system can develop and improve corporate governance } \\
\text { and achieve its goals faster. Purposeful evaluation system means the existence } \\
\text { of correct criteria for evaluation, evaluation and accurate monitoring and im- } \\
\text { plementation of corrective feedback. In this research, the existence of a system- } \\
\text { atic evaluation system, the correct implementation of evaluation and appropri- } \\
\text { ate feedback, and the existence of strong incentives and punitive levers are rec- } \\
\text { ognized as codes explaining the concept of appropriate performance evaluation } \\
\text { system. }\end{array}$ \\
\hline Improving economic indicators & $\begin{array}{l}\text { This concept means all the benefits that can improve the company financially } \\
\text { and economically. Reducing costs, improving the economic situation, improv- } \\
\text { ing the quality of auditing, increasing the profitability of the codes that are ex- } \\
\text { pressed in the form of this concept. }\end{array}$ \\
\hline Firm risk control & $\begin{array}{l}\text { Effective corporate governance mechanisms, as a risk management tool, ensure } \\
\text { the optimal risk-taking of financial institutions in a better way than the legal } \\
\text { requirements. Corporate governance is the management of conflict between all } \\
\text { stakeholders of the organization. This definition is based on stakeholder theory. } \\
\text { In this study, the concept of firm risk control is explained in three codes: in- } \\
\text { creasing riskiness, reducing conflict of interest between stakeholders and reduc- } \\
\text { ing financial risks. }\end{array}$ \\
\hline $\begin{array}{l}\text { Increase the organization's financial re- } \\
\text { sources }\end{array}$ & $\begin{array}{l}\text { In this study, increasing the number of shareholders, increasing the amount of } \\
\text { shareholders 'capital, reducing the desire to leave or reducing the shareholders' } \\
\text { capital have been introduced as sub-codes of the concept of increasing the or- } \\
\text { ganization's financial resources. }\end{array}$ \\
\hline $\begin{array}{l}\text { Increase the trust and credibility of the or- } \\
\text { ganization }\end{array}$ & $\begin{array}{l}\text { Increasing the trust and credibility of the organization in this study is explained } \\
\text { by the two concepts of trust and public legitimacy and promoting the status and } \\
\text { credibility of the organization. The issue of public trust is the most valuable } \\
\text { component of social capital. Legitimacy is the public agreement that makes an } \\
\text { organization's actions acceptable, correct, and desirable. By gaining the legiti- } \\
\text { macy of the organization, they can gain more resources, reputation and ad- } \\
\text { vantages in the competitive market. }\end{array}$ \\
\hline $\begin{array}{l}\text { Agility and increase the competitive power of } \\
\text { the organization }\end{array}$ & $\begin{array}{l}\text { The ability of organizations to sense any unforeseen changes in the market or } \\
\text { customer preferences and then respond quickly to them can be a consequence } \\
\text { of corporate governance in the context of rationality. In this research, three } \\
\text { codes of rapid response to change, increasing competitiveness, updating } \\
\text { knowledge and technology explain this concept. }\end{array}$ \\
\hline
\end{tabular}


Farrokh- Seresht B. et al.

International Journal of Ethics \& Society (IJES), (2021) Vol. 3, No. 1

\begin{tabular}{|l|l|}
\hline $\begin{array}{l}\text { Improve the operational performance of the } \\
\text { organization }\end{array}$ & $\begin{array}{l}\text { Corporate governance mechanisms help investors to stimulate and force man- } \\
\text { agement elements to use companies' resources more efficiently in order to per- } \\
\text { form their managerial duties. Proper use of resources, increasing efficiency and } \\
\text { sustainable development are concepts that improve the performance of a com- } \\
\text { pany in terms of performance and are expressed in the form of a concept. }\end{array}$ \\
\hline Promoting business ethics & $\begin{array}{l}\text { Ethics is the application and institutionalization of values in individuals and val- } \\
\text { ues that reflect accepted principles and laws. Improving the quality of services, } \\
\text { increasing organizational order, improving organizational relationships and be- } \\
\text { havior, and adhering to professional ethics as sub-codes of this concept have } \\
\text { been explained in this research. }\end{array}$ \\
\hline Trust and value creation for shareholders & $\begin{array}{l}\text { Shareholders are the main owners of business units and the main goal of busi- } \\
\text { ness units is to maximize shareholder wealth. In this research, providing maxi- } \\
\text { mum profit and benefits to shareholders, creating a sense of trust in sharehold- } \\
\text { ers towards the company, feeling of shareholders' satisfaction and strengthening } \\
\text { their loyalty are explained as codes explaining the concept of trust and value } \\
\text { creation for shareholders. }\end{array}$ \\
\hline
\end{tabular}

\section{Selective coding}

Selective coding is the process of integrating and improving categories. At this stage of coding, a theory of the relationships between the categories in the axial coding model is written. In other words, selective coding captures the findings of the previous coding steps, selects the central category, systematically relates it to other categories, proves those relationships, and the categories that need further improvement and development. It completes; therefore, the central category is a very important part of the integration and improvement of categories. Table 2 shows the selected coding categories.

\section{Table 2: Selective coding}

\begin{tabular}{|c|c|}
\hline Type of Category & Category \\
\hline Axial category & Good corporate governance \\
\hline \multirow{7}{*}{ Causative conditions } & Type of joint stock company (ownership and control) \\
\hline & Type of structure and responsibilities of the board \\
\hline & The need for transparency and disclosure of information \\
\hline & Establishing justice and fairness among stakeholders \\
\hline & The need to pay attention to the role of stakeholders and respect their rights \\
\hline & The need to reduce corruption and financial abuses \\
\hline & Tendency to privatize companies \\
\hline \multirow{2}{*}{ Context conditions } & Rationality \\
\hline & Ethics \\
\hline \multirow{8}{*}{ Strategies } & Develop and adopt appropriate strategies \\
\hline & Appropriate rules and regulations and monitoring its proper implementation \\
\hline & Organizational culture is in line with the values of corporate governance \\
\hline & $\begin{array}{l}\text { An experienced, capable, ethical and committed board of directors with a } \\
\text { sense of governance }\end{array}$ \\
\hline & $\begin{array}{l}\text { Establish a balance between corporate governance and organizational char- } \\
\text { acteristics }\end{array}$ \\
\hline & Training and knowledge sharing between members \\
\hline & $\begin{array}{l}\text { Establish appropriate relationships with stakeholders and stakeholder par- } \\
\text { ticipation }\end{array}$ \\
\hline & Appropriate performance evaluation system \\
\hline \multirow{3}{*}{ Intervention conditions } & Economic conditions governing society \\
\hline & Policies and laws of government and governing institutions \\
\hline & Corporate social responsibility \\
\hline \multirow{5}{*}{ Consequences } & Improving economic indicators \\
\hline & Firm risk control \\
\hline & Increase the organization's financial resources \\
\hline & Increase the trust and credibility of the organization \\
\hline & Agility and increase the competitive power of the organization \\
\hline
\end{tabular}




\begin{tabular}{|l|l|}
\hline \multirow{2}{*}{} & Improve the operational performance of the organization \\
\cline { 2 - 2 } & Promoting business ethics \\
\cline { 2 - 2 } & Trust and value creation for stakeholders \\
\hline
\end{tabular}

According to the above explanations and the results of the interviews, the model of good corporate governance in the context of ethics and rationality is shown in Figure 1, which is the main model of this research with the model of grounded theory.

\section{Discussion}

According to the results of the present study, achieving good corporate governance requires rational and ethical contexts, and in this way a number of causal conditions must be included: type of joint stock Company (ownership and control), type of structure and responsibilities of the board, the need for transparency and disclosure. Information, establishing justice and fairness among stakeholders, the need to pay attention to the role of stakeholders and respect their rights, the need to reduce corruption and financial abuses, the tendency to privatize companies should be considered. Some researchers (10-12) have examined rationality and its role in decision making which can confirm this result; but there is no research that specifically examines the role of rationality in implementing corporate governance strategies. In the field of corporate governance indicators, although the extractive indicators in this study can be seen in other domestic and foreign studies, but so far, a comprehensive model has not been observed that examines all the causal conditions.

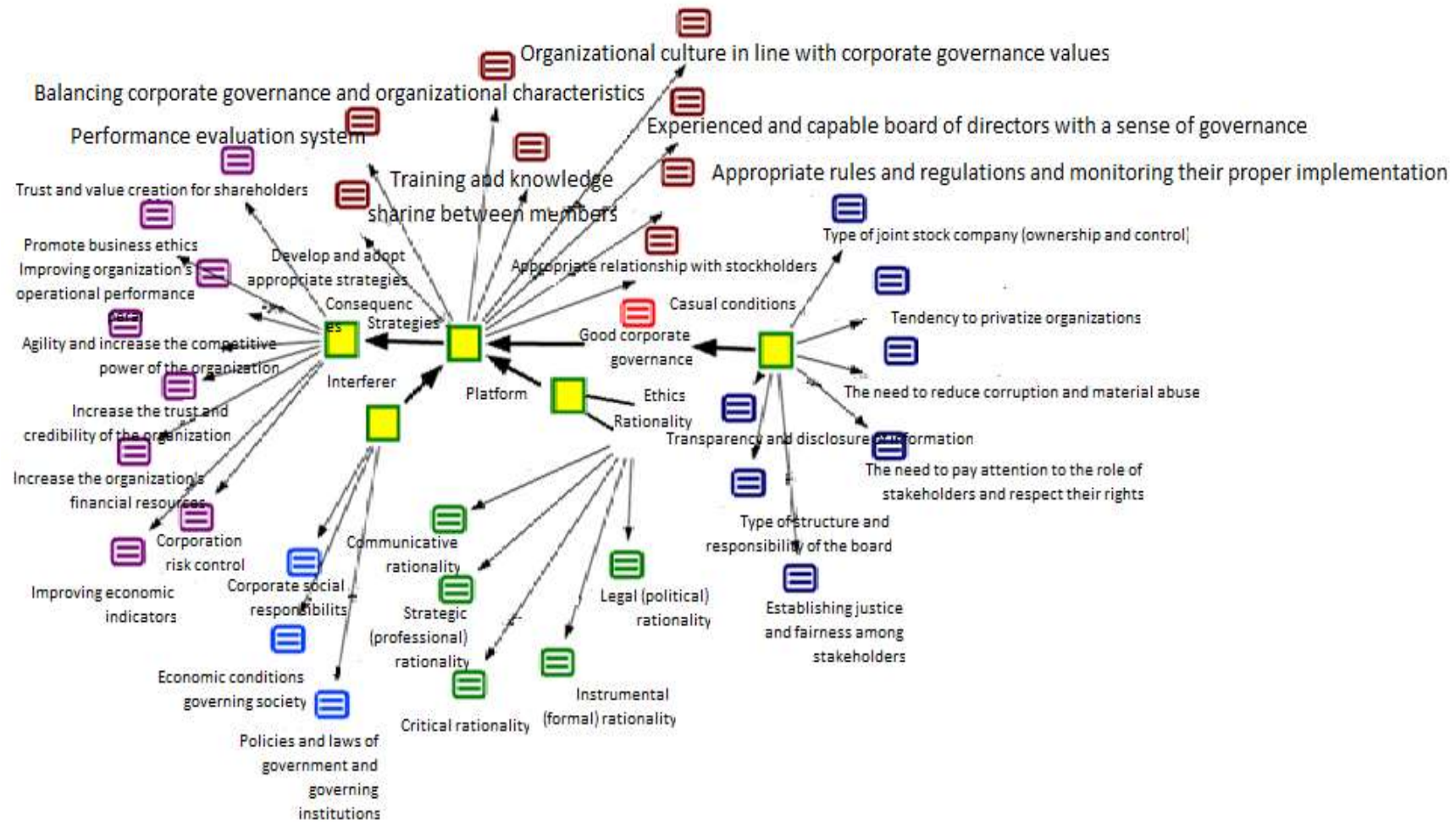

Fig. 1: Data theory model of corporate governance foundation in the context of ethics and rationality 
Also, according to the results of the present study, the strategies to achieve good corporate governance are: formulating and adopting appropriate strategies, appropriate laws and regulations and monitoring its proper implementation, organizational culture in line with corporate governance values, experienced, capable and ethical board with committed governance, Establishing a balance between corporate governance and organizational characteristics, training and knowledge sharing among members, establishing appropriate relationships with stakeholders and stakeholder participation, and an appropriate performance appraisal system. Many researches inside and outside the country have examined the effective indicators on corporate governance and its strategies. For example, some researchers (13) in their research cited the legal structure for corporate activity, targeted government ownership, equity treatment, stakeholder trust, information disclosure and transparency, clarity of board responsibilities as indicators of public sector governance that can confirm the results of the present study. Other researchers (14-16) in their research have studied the indicators and strategies of good corporate governance, which is somewhat consistent with the present study.

In the research model, the intervening conditions were the economic conditions prevailing in the society, the policies and laws of the government and governing institutions, the social responsibility of the company, which is in line with the results of some researches $(17,18)$.

Implications emphasized in the present research model include: improving economic indicators, controlling firm risk, increasing the organization's financial resources; Increasing the trust and credibility of the organization, agility and increasing the competitiveness of the organization, improving the operational performance of the organization, promoting business ethics and trust and value creation for shareholders were emphasized in some studies $(19,20)$.

In the end, it is suggested that the managers and officials of Tehran Water and Sewerage Company and all decision-making institutions consider the results of this research and use their efforts to implement a good corporate governance model in the organization by using it properly and instead of all kinds of rationality. Provide the consent of all stakeholders for the company. Other researchers need to quantify the extraction model and test the results for other organizations as well.

\section{Conclusion}

Considering the privatization of ABFA Tehran and becoming a joint stock company, there should be monitoring and control in order to increase transparency and accountability to reduce corruption and pay attention to the rights of all stakeholders, which requires a good corporate governance model. Based on the results of the present study, the implementation of the corporate governance model should be done in the context of ethics and rationality. The formulation and adoption of strategies appropriate to corporate governance should be done in the context of strategic rationality and critical rationality, instrumental rationality, and communicative rationality. Legal rationality also states the necessary ground for enacting appropriate laws and regulations. In addition, business ethics, which is rooted in rationality, is an important ethical framework for corporate governance and specifies that in setting laws, ethics and social responsibilities of the company should be considered.

\section{Ethical Consideration}

Moral issues (such as plagiarism, conscious satisfaction, misleading, making and or forging data, publishing or sending to two places, redundancy and etc.) have been fully considered by the writers.

\section{Acknowledgement}

Researchers consider it necessary to thank and appreciate all the participants who helped us in this research. 


\section{References}

1. Nadi Qomi W, Hosseini SF, Mostafavi SF (2020). Investigating the effect of the power of corporate governance mechanisms on the systemic risk of financial institutions listed on the Tehran Stock Exchange. Financial Research, 22(2): 205-226. (In Persian)

2. Polovina N, Peasnell K (2020). Do minority acquisitions transfer better corporate governance practices? An analysis of UK's cross-border minority investments. The British Accounting Review, 52(3):100-897.

3. Srivastava G, Kathuria V (2020). Impact of corporate governance norms on the performance of Indian utilities. Energy Policy, 140:111-414.

4. Ahani M, Musa Khani M, Najaf Beigi R, Afshar Kazemi MA (2018). Cluster analysis of Iran's position in the world and future trends based on good governance components. Future Management Research Quarterly, 30(116): 99118.(In Persian)

5. Gunawan CC, Murhadi WR, Utami M (2019). A study on the effects of good corporate governance-gender diversity on the company performance. $16^{\text {th }}$ International Symposium on Management, Atlantis Press/Paris.

6. Sepasi S (2014). Relationship between corporate governance and creation of professional codes of conduct. Ethics in Science and Tecbnology; 9 (1). (In Persian).

7. Shurvarz MR, Khalili M, Soleimani H, Frotan O (2015). The relationship between corporate governance and firm performance based on fuzzy regression. Journal of Financial Accounting and Auditing, 7(25): 121-139. (In Persian)

8. Tricker RB, Tricker RI (2015). Corporate governance: Principles, policies, and practices. Oxford University Press, USA.

9. Naghibzade M, Nowrozi R (2010). Analytic study of habermas' view on moral and social education goals: emphasizing on communicative action theory. Joumal of Applied Sociology, 21(1): 123-142. (In Persian)

10. Sheikhzadeh M, Sheikhzadeh R (2007). Examining the foundations of rationality in decision making. Strategic Management Thought, 1(1): 151-164. (In Persian).
11. Danaiefard H, Saghafi E, Moshabaki A (2012). Public policy implementation: explaining the role of rationality in policy formulation. Management Research, 14(4): 79-106. (In Persian)

12. Barzegar E, Hoseinzadeh S (2016). Study on rationality of public policy making in Iran. Public Policy, 2(1): 51-79. (In Persian)

13. Gholipoor R, Mashayekhi B, Naseri A (2010). Corporate governance in public sector and its role in economy of resistance. Journal of Fiscal and Economic Policies, 4(14): 107-130. (In Persian)

14. Harris JE (2009). A review of Latin American corporate governance literature: 2000-2009. Corporate Governance: The International Journal of Business in Society.

15. Foerster SR, Huen BC (2004). Does corporate governance matter to Canadian investors? Canadian Investment $\mathrm{R} e-$ view, 17(3): 19-23.

16. Gull AA, Saeed A, Abid A (2013). Corporate governance and performance: An empirical evidence from textile sector of Pakistan. African Journal of Business Management, 7(22): 2112-2118.

17. Safarian R, Imam Jomehzadh SJ (2017). The model of good governance; social capital and all-round development. Journal of Government Studies, 3(12): 145-181. (In Persian).

18. Ebrahimpour H, Oleiki $F$ (2016). Investigating the role of good governance in the efficiency of governments. International Conference of Management Elites, Tehran/Iran.

19. Nejatian M, Hosnavi R, Zanjirchi SM, Soufi H, Molaee ME (2013). Analysis of the agility paradigm for a specific framework of agile manpower and agile organization. Journal of Management Improvement, 7(2): 77-98. (In Persian).

20. Zakipour M, Rostami M, Saeenia H (2015). Promoting organizational agility through human resource management functions. Journal of Human Resource Studies, 6(19): 27-45. (In Persian). 